\title{
PTEROMALIDAE OF LAGODEKHI PROTECTED AREAS WITH THE DESCRIPTION OF A NEW PSILOCERA SPECIES FROM SAKARTVELO (GEORGIA)
}

\author{
Zoltán László ${ }^{1,2}$, Tünde-Ilona Kelemen ${ }^{1}$ and George Japoshvili ${ }^{3,4}$ \\ ${ }^{1}$ Hungarian Department of Biology and Ecology, Babeș-Bolyai University \\ Cluj-Napoca 400006, Romania, E-mails: zoltan.laszlo@ubbcluj.ro \\ https://orcid.org/0000-0001-5064-4785; kelementundeilona92@gmail.com \\ https://orcid.org/0000-0001-6963-9222 \\ ${ }^{2}$ Center for Systematic Biology, Biodiversity and Bioresources (3B Center) \\ Cluj-Napoca 400006, Romania \\ ${ }^{3}$ Institute of Entomology, Agricultural University of Georgia, $13 \mathrm{~km}$ David Agmashenebeli Alley \\ 0159 Tbilisi, Georgia, E-mail: g.japoshvili@agruni.edu.ge \\ https://orcid.org/0000-0002-9901-4554 \\ ${ }^{4}$ Invertebrate Research Centre, Tetritsklebi, 2200 Telavi, Georgia
}

\begin{abstract}
We present an annotated check-list of Pteromalidae (Hymenoptera: Chalcidoidea) from Sakartvelo (the Republic of Georgia), updating the available information of these parasitoids. We identified 22 species belonging to 17 genera from 9 subfamilies - Asaphinae, Cerocephalinae, Cleonyminae, Miscogastrinae, Pteromalinae and Spalangiinae. One species, Psilocera kartveli László et Kelemen sp. n., is described as a new for science, and the remaining 21 species are new records for the fauna of Georgia, from which 10 species are new for the Caucasus. All the 17 genera are recorded for the first time for the Georgian fauna. For each species, their biology and distribution are presented.
\end{abstract}

Key words: Caucasus, Malaise-trap, Sakartvelo, Asaphes vulgaris phenology, species description

\section{INTRODUCTION}

The superfamily Chalcidoidea is one of the largest within parasitic Hymenoptera, including more than 20,000 described species (Noyes 2019). Chalcidoids are usually parasitoids having major importance in the biological control of insect pests (VAN Driesche et al. 2008). The family Pteromalidae is one of the most specious families belonging to the Chalcidoidea, one of the three largest in the superfamily (Desjardins et al. 2007). The high number of species is due mainly to the most specious subfamilies Pteromalinae and Miscogastrinae (Dzhanokmen 1988), while several other subfamilies are represented by significantly fewer species, and some of them only by a few described species (Noyes 2019). Pteromalids mostly develop as parasitoids of various insects, or even arachnoids, only a few being phytophagous (BoučEK \& RAsplus 1991). Pteromalids are not defined by any unique character or combination of characters. Therefore they are called the "sampling ground" or "dumping ground" of the 
chalcidoids 'pteromalid lineage' (Boucek \& Heydon 1997, TöRÖк \& AвraHAM 2002). The Pteromalidae family is known to be polyphyletic, actually being a conglomeration of different taxa with no clearly defined boundaries and position (TöröK \& Aвraham 2002, Desjardins et al. 2007, Munro et al. 2011, Heraty et al. 2013). However, the Pteromalidae family currently includes 588 genera and 3506 species, placed in 31 subfamilies (Noyes 2019).

The species from the family Pteromalidae are poorly known in Georgia (Japoshvili 2002, Noyes 2019). Several species from the recorded ones are of economic importance like Pachyneuron muscarum (Linnaeus, 1758) (YASNOSH et al. 2001, Japoshvili \& Karaca 2002), Scutellista caerulea (Fonscolombe, 1832) (Рroкореnко \& Mokrousova 1981), S. obscura (Förster, 1878) (Yasnosh 1972), Caenocrepis arenicola (Thomson, 1878) (BочčEк 1958) or Eunotus obscurus Masi, 1931 (YAsNosh 1972). A few species were described based on specimens collected in Georgia like Systasis ephedrae Dzhanokmen, 1982 (Dzhanokmen 1982) or Notanisus clavatus Bouček, 1961 (Bouček 1961). Others, like Eunotus cretaceus Walker, 1834, Cecidostiba geganius (Walker, 1848), Dinarmus basalis (Rondani, 1877), Metacolus azureus Foerster, 1856, Mesopolobus graminum (Hardh, 1950), N. versicolor Walker, 1837, P. solitarium (Hartig, 1838), Pteromalus puparum (Linnaeus, 1758), Rhopalicus tutela (Walker, 1836) and Roptrocerus brevicornis Thomson, 1878, were listed from Georgia in different publications (GraHAM 1969, Yasnosh 1972, Dzhanokmen 1978, Japoshvili 2002, Dzhanokmen 2005, TSELIKH 2011).

In the present paper, we aim to present the species belonging to the family Pteromalidae collected in Georgia by Malaise-traps in the Lagodekhi protected areas and thus broaden the regional knowledge of the family.

\section{MATERIAL AND METHODS}

The material was collected in Lagodekhi protected areas with Malaise traps (B\&N Entomological services: http://www.entomology.org.uk/). The Lagodekhi reserve is one of the oldest protected areas in Georgia, established in 1912 and is located in the extreme north-eastern part of the southern slopes of Georgia and southern slopes of the Caucasus Mountains with a range of altitudes from 590 to $3500 \mathrm{~m}$.

Collecting began on 2 April 2014 and lasted until 7 November 2014, although in alpine and subalpine areas collecting began later (subalpine 5 May 2014, alpine 23 May 2014) and was completed earlier (6 October 2014) due to climate conditions at higher altitudes. Malaise traps were placed in seven different areas with the following vertical zonal characteristics: $\mathrm{H} 1$ : low-altitude forest, $666 \mathrm{~m}, 41.852441^{\circ} \mathrm{N} 46.287771^{\circ} \mathrm{E}, \mathrm{H} 2$ : mid-altitude forest, $847 \mathrm{~m}, 41.855848^{\circ} \mathrm{N} 46.292739^{\circ} \mathrm{E}, \mathrm{H} 3$ : high-altitude forest, $1351 \mathrm{~m}, 41.871523^{\circ} \mathrm{N}$ $46.311585^{\circ} \mathrm{E}$, H4: subalpine forest, $1841 \mathrm{~m}, 41.882783^{\circ} \mathrm{N} 46.321886^{\circ} \mathrm{E}, \mathrm{H} 4-5$ : subalpine forest $1902 \mathrm{~m}, 41.885674^{\circ} \mathrm{N} 46.324132^{\circ} \mathrm{E}, \mathrm{H} 5$ : subalpine meadows and shrublands, $2230 \mathrm{~m}$, $41.898092^{\circ} \mathrm{N} 46.333940^{\circ} \mathrm{E}, \mathrm{H} 6$ : alpine zone, $2559 \mathrm{~m}, 41.906257^{\circ} \mathrm{N} 46.333441^{\circ} \mathrm{E}$. 
Traps were surveyed and emptied every $10( \pm 2)$ days, and collected insect material was placed in $96 \%$ ethanol and later sorted, CPD dried and mounted according (Noyes 2019). After sorting to families, the pteromalids were screened, sorted, and prepared for identification. All voucher and type specimens are deposited in the Entomological Collection of the Institute of Entomology, Agricultural University of Georgia, Tbilisi, Georgia (IEAUG) and in the Museum of Zoology, Babeş-Bolyai University, Cluj-Napoca (MZBBU).

Photographs were made using an Olympus SZ51 stereo microscope (110AL2×-2 auxiliary and a WHSZ10 $\times$ objective lens) with a mounted Canon EOS 600D DSLR camera by an LMscope adapter (30 mm tube adapter for LM digital SLR adapter with $23.2 \mathrm{~mm}$ tube). Photographs were stacked with Photoshop CS5 auto-blend layer function.

Species recorded for the first time for the Caucasus are marked with two asterisks, new species for Georgia with only one asterisk.

\title{
RESULTS
}

1010 specimens were studied from the collected material, which belongs to the family of Pteromalidae (Hymenoptera, Chalcidoidea). The studied specimens belong to 22 species and 7 subfamilies (Asaphinae, Cerocephalinae, Cleonyminae, Diparinae, Miscogasterinae, Pteromalinae, Spalangiinae).

\author{
Family Pteromalidae Dalman, 1820 \\ Subfamily Asaphinae Ashmead, 1904 \\ Genus Asaphes Walker, 1834
}

\section{Asaphes vulgaris Walker, 1834 *}

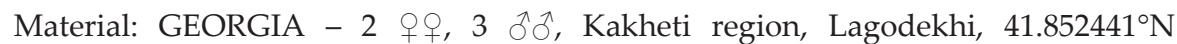
46.287771 ${ }^{\circ}$, alt. 666 m, 12 Apr.-15 May 2014, Japoshvili G. leg., H1, deposited in MZBBU; 8 우, Kakheti region, Lagodekhi, $41.855848^{\circ} \mathrm{N} 46.292739^{\circ} \mathrm{E}$, alt. $847 \mathrm{~m}, 24$ Apr.-15 Jul. 2014, Japoshvili G. leg., H2, deposited in MZBBU; 58 웅, 39 $\widehat{\jmath}$, Kakheti region, Lagodekhi, $41.871523^{\circ} \mathrm{N} 46.311585^{\circ} \mathrm{E}$, alt. $1351 \mathrm{~m}, 5$ May-6 Oct. 2014, Japoshvili G. leg., H3, deposited in IEAUG; 246 우, 70 ○े $\widehat{\jmath}$, Kakheti region, Lagodekhi, $41.882783^{\circ} \mathrm{N} 46.321886^{\circ} \mathrm{E}$, alt. 1841 m, 15 May-6 Oct. 2014, Japoshvili G. leg., H4, deposited in MZBBU; 175 우, 87 $\widehat{\delta} \widehat{\sigma}^{\lambda}$, Kakheti region, Lagodekhi, $41.885674^{\circ} \mathrm{N} 46.324132^{\circ} \mathrm{E}$, alt. 1902 m, 5 May-6 Oct. 2014, Japoshvili G. leg., H4-5, deposited in MZBBU; 78 우우 23 수, Kakheti region, Lagodekhi, $41.898092^{\circ} \mathrm{N} 46.333940^{\circ} \mathrm{E}$, alt. $2230 \mathrm{~m}, 25$ May-4 Sep. 2014, Japoshvili G. leg., H5, deposited in IEAUG; 71 우, 12 ๙ิ $^{\circ}$, Kakheti region, Lagodekhi, $41.906257^{\circ} \mathrm{N} 46.333441^{\circ} \mathrm{E}$, alt. $2559 \mathrm{~m}$, 25 Jun. 2014-6 Oct. 2014, Japoshvili G. leg., H6, deposited in MZBBU.

There were collected 645 female and 243 male specimens of this species. Thus it was the most numerous species recorded during our survey. Regarding their phenology, their numbers peaked in July on mid altitude forest level (H4) (Fig. 1). 
Biology: generalist hyperparasitoid in many species of aphids through Aphidiinae (Braconidae) with at least two yearly-generations (GrAнAm 1969). In Noyes (2019) several other primary hosts are enumerated, including also various Diptera and Hymenoptera species.

Distribution: cosmopolitan species, widely distributed also in the whole Palaearctic (Noyes 2019). Was previously not recorded from Georgia.

\section{Subfamily Cerocephalinae Gahan, 1946 \\ Genus Cerocephala Westwood, 1832 \\ Cerocephala cornigera Westwood, 1832*}

Material: GEORGIA - 1 ㅇ, Kakheti region, Lagodekhi, $41.852441^{\circ} \mathrm{N} 46.287771^{\circ} \mathrm{E}$, alt. 666 m, 25 May 2014-4 Jun. 2014, Japoshvili G. leg., H1, deposited in MZBBU.

Biology: parasitoid of several species and genera of Scolytidae (Graham 1969), but also of species belonging to several other Coleoptera families (Noyes 2019).

Distribution: Palearctic, already recorded from the Caucasus, but not from Georgia (BoučEk 1966 in Noyes 2019).
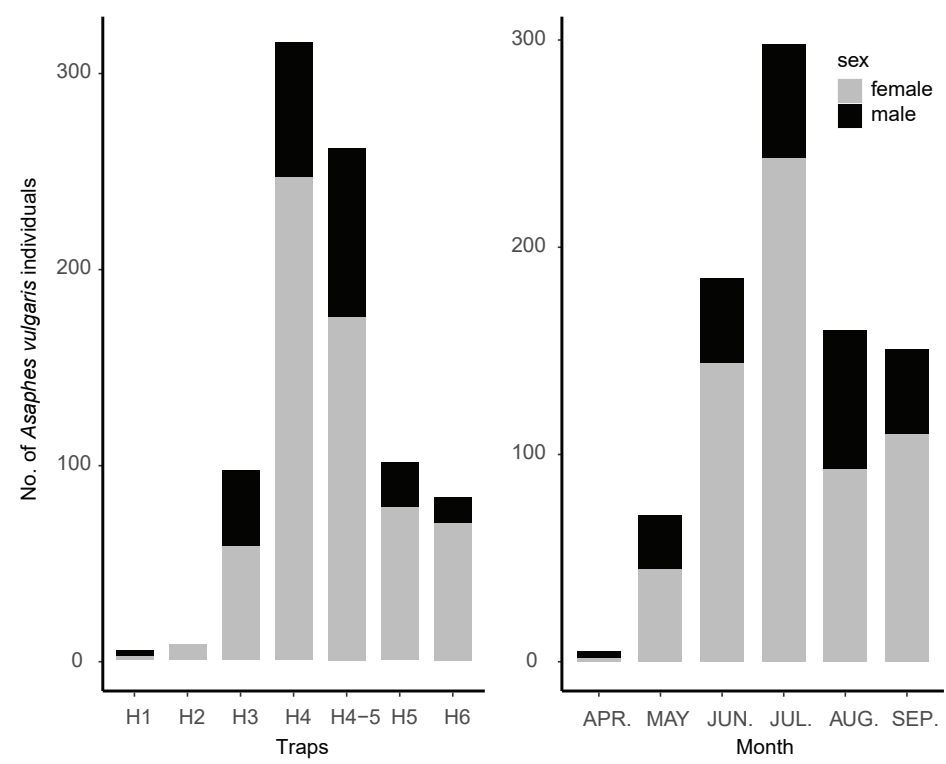

Fig. 1. Phenology of the species Asaphes vulgaris (Hymenoptera, Pteromalidae) in the Lagodekhi Nature Reserve in year 2014, based on Malaise-trap data. Trap ID: H1 = low-altitude forest (alt. $666 \mathrm{~m}), \mathrm{H} 2$ = mid-altitude forest (alt. $847 \mathrm{~m}$ ), H3 = high-altitude forest (alt. $1351 \mathrm{~m}), \mathrm{H} 4$ = subalpine forest (alt. $1841 \mathrm{~m}), \mathrm{H} 4-5$ = subalpine forest (alt. $1902 \mathrm{~m}), \mathrm{H} 5$ = subalpine meadows and shrublands (alt. $2230 \mathrm{~m}), \mathrm{H} 6=$ alpine zone (2559 m) 


\section{Subfamily Cleonyminae Walker, 1837}

Genus Cleonymus Latreille, 1809 Cleonymus brevis Bouček, 1972 **

(Fig. 2a, b)

Material: GEORGIA - 2 우, Kakheti region, Lagodekhi, $41.852441^{\circ} \mathrm{N} 46.287771^{\circ} \mathrm{E}$, alt. 666 m, 26 Jul.-15 Aug. 2014, Japoshvili G. leg., H1, deposited in MZBBU; 3 q , Kakheti region, Lagodekhi, $41.855848^{\circ} \mathrm{N} 46.292739^{\circ} \mathrm{E}$, alt. $847 \mathrm{~m}, 5$ Jul.-4 Sep. 2014, Japoshvili G. leg., $\mathrm{H} 2$, deposited in IEAUG; 1 ㅇ, Kakheti region, Lagodekhi, $41.882783^{\circ} \mathrm{N} 46.321886^{\circ} \mathrm{E}$, alt. 1841 m, 15-27 Sep. 2014, Japoshvili G. leg., H4, deposited in MZBBU.

Biology: parasitoid of xylophagous Coleoptera, reared from Hylesinus toranio (D’Anthoine, 1788) (BoučEK 1972).

Distribution: widely in Europe (BoučEK 1972, Noyes 2019), but not recorded from the Caucasus or Georgia.

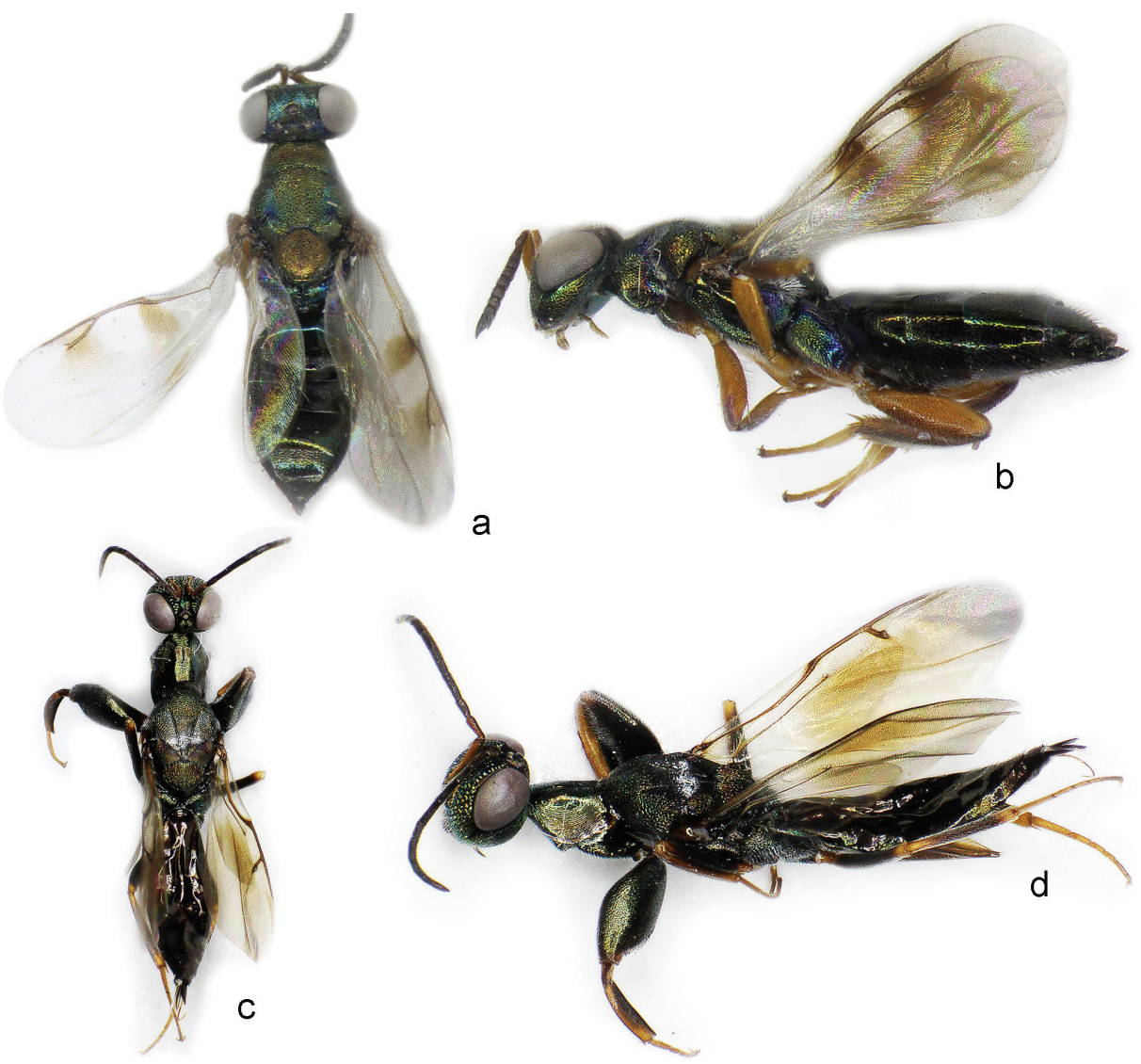

Fig. 2. Dorsal and lateral views of Cleonyminae species collected in the Lagodekhi protected areas: $\mathrm{a}-\mathrm{b}=$ Cleonymus brevis Bouček, 1972, c- $\mathrm{d}=$ Oodera formosa (Giraud, 1863) 


\title{
Genus Oodera Westwood, 1874 \\ Oodera formosa (Giraud, 1863) *
}

(Fig. 2c, d)

Material: GEORGIA - 1 , Kakheti region, Lagodekhi, $41.855848^{\circ} \mathrm{N} 46.292739^{\circ} \mathrm{E}$, alt. 847 m, 15-25 Jul. 2014, Japoshvili G. leg., H2, deposited in MZBBU; 1 ㅇ, Kakheti region, Lagodekhi, $41.882783^{\circ} \mathrm{N} 46.321886^{\circ} \mathrm{E}$, alt. $1841 \mathrm{~m}, 15-27$ Sep. 2014, Japoshvili G. leg., H4, deposited in IEAUG.

Biology: parasitoid of xylophagous beetles, mainly from families Buprestidae and Scolytidae (BoučEK \& RAsplus 1991). The taxonomic placement of the genus Oodera is still not clearly defined, momentarily being placed into the family Pteromalidae (Heraty et al. 2013, Werner \& Peters 2018).

Distribution: with Palearctic distribution, known from Europe and Russian Federation, also from the Caucasus, but not recorded in Georgia until now (Noyes 2019).

\section{Subfamily Diparinae Thomson, 1876}

\author{
Genus Dipara Walker, 1833 \\ Dipara petiolata Walker, 1833 **
}

Material: GEORGIA - 1 , , Kakheti region, Lagodekhi, $41.855848^{\circ} \mathrm{N} 46.292739^{\circ} \mathrm{E}$, alt. 847 m, 2 Apr. 2014-7 Nov. 2014, Japoshvili G. leg., H2, deposited in MZBBU; 1 , , Kakheti region, Lagodekhi, $41.882783^{\circ} \mathrm{N} 46.321886^{\circ} \mathrm{E}$, alt. $1841 \mathrm{~m}, 15-27$ Sep. 2014, Japoshvili G. leg., H4, deposited in IEAUG.

Biology: no host records until now, but probably parasitic of Curculionidae on plant roots, based on data from India (BоučEK \& RAsplus 1991).

Distribution: widely distributed in Europe, with records from Middle East and the United States (Noyes 2019). Not recorded from the Caucasus or Georgia until now.

\section{Subfamily Miscogastrinae Walker, 1833}

\section{Genus Gastracanthus Westwood, 1833 \\ Gastracanthus pulcherrimus Westwood, $1833^{\text {** }}$}

Material: GEORGIA - 1 ㅇ, Kakheti region, Lagodekhi, $41.882783^{\circ} \mathrm{N} 46.321886^{\circ} \mathrm{E}$, alt. 1841 m, 25 May-4 Jun. 2014, Japoshvili G. leg., H4, deposited in MZBBU.

Biology: may often be found on the foliage of Corylus avellana L. (Graнam 1969) and in the nearby vegetation of dead wood in Querceto-Carpinetum forest undergrowth (pers. obs.). Enumerated primary hosts belong to Buprestidae and Byrrhidae (Noyes 2019).

Distribution: widely distributed in Europe (Graham 1969, Noyes 2019). Not recorded from the Caucasus or Georgia until now. 


\section{Genus Janssoniella Kerrich, 1957 \\ Janssoniella caudata Kerrich, 1957 **}

Material: GEORGIA - 1 ㅇ, Kakheti region, Lagodekhi, $41.871523^{\circ} \mathrm{N} 46.311585^{\circ} \mathrm{E}$, alt. 1351 m, 3 May 2014, Japoshvili G. leg., H3, deposited in MZBBU.

Biology: It was reared from polypore mushroom (Trametes (syn. Polyporus) versicolor (Lloyd, 1920)) (Graham 1969), thus it may be parasitoid in beetles (like the other species from the tribe Trigonoderini) inhabiting the mushroom, but also Diptera can be considered as primary hosts.

Distribution: it is known from Europe, Nearctic and Russian Far East (Noyes 2019). Not recorded from the Caucasus or Georgia until now.

\section{Genus Miscogaster Walker, 1833 Miscogaster rufipes Walker, 1833 **}

Material: GEORGIA - 2 우, Kakheti region, Lagodekhi, $41.855848^{\circ} \mathrm{N} 46.292739^{\circ} \mathrm{E}$, alt.

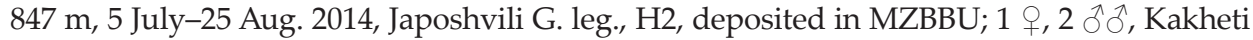
region, Lagodekhi, $41.871523^{\circ} \mathrm{N} 46.311585^{\circ} \mathrm{E}$, alt. $1351 \mathrm{~m}, 15-25$ July 2014 , Japoshvili G. leg.,

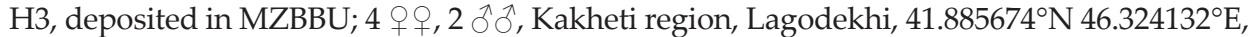
alt. 1902 m, 15-25 July 2014, Japoshvili G. leg., H4-5, deposited in IEAUG; 1 +, Kakheti region, Lagodekhi, $41.898092^{\circ} \mathrm{N} 46.333940^{\circ} \mathrm{E}$, alt. 2230 m, 15-25 Aug. 2014, Japoshvili G. leg., $\mathrm{H} 5$, deposited in MZBBU; 3 우우 , Kakheti region, Lagodekhi, $41.906257^{\circ} \mathrm{N} 46.333441^{\circ} \mathrm{E}$, alt. 2559 m, 15 June 2014-14 Sep. 2014, Japoshvili G. leg., alpine zone (H6), deposited in IEAUG.

Biology: parasitoid of leaf-miner flies (Diptera: Agromyzidae) mining in several plant species from families Boraginaceae, Ranunculaceae and Urticaceae (Graham 1969, Noyes 2019).

Distribution: widely distributed in Europe, and recorded from Kazakhstan (DzHANoKmen 2005, Noyes 2019). New fom the Caucasus and Georgia.

\section{Genus Plutothrix Foerster, 1856 \\ Plutothrix bicolorata (Spinola, 1808) **}

Material: GEORGIA -8 우, Kakheti region, Lagodekhi, $41.852441^{\circ} \mathrm{N} 46.287771^{\circ} \mathrm{E}$, alt. 666 m, 23 Apr.-15 Aug. 2014, Japoshvili G. leg., low altitude forest (H1), deposited in MZBBU; 10 우우, Kakheti region, Lagodekhi, $41.871523^{\circ} \mathrm{N} 46.311585^{\circ} \mathrm{E}$, alt. $1351 \mathrm{~m}, 3$ May-6 Oct. 2014, Japoshvili G. leg., high-altitude forest (H3), deposited in MZBBU; 1 , Kakheti region, Lagodekhi, $41.882783^{\circ} \mathrm{N} 46.321886^{\circ} \mathrm{E}$, alt. $1841 \mathrm{~m}$, 15 Aug. 2014, Japoshvili G. leg., $\mathrm{H} 4$, deposited in MZBBU; 4 우, Kakheti region, Lagodekhi, $41.885674^{\circ} \mathrm{N} 46.324132^{\circ} \mathrm{E}$, alt. 1902 m, 4 June-25 July 2014, Japoshvili G. leg., H4-5, deposited in IEAUG.

Biology: parasitoid of anobiid beetles (Coleoptera: Anobiidae) (Graham 1969). May often be found in the undergrowth of hedgerows with bushy Fabaceae (pers. obs.).

Distribution: widely distributed in Europe (Graham 1969, Noyes 2019). Not recorded from the Caucasus or Georgia until now. 
Genus Sphegigaster Spinola, 1811

Sphegigaster pallicornis (Spinola, 1808) **

Material: GEORGIA - 1 , Kakheti region, Lagodekhi, $41.852441^{\circ} \mathrm{N} 46.287771^{\circ} \mathrm{E}$, alt. 666 m, 2-12 Apr. 2014, Japoshvili G. leg., H1, deposited in MZBBU; 1 , Kakheti region, Lagodekhi, $41.882783^{\circ} \mathrm{N} 46.321886^{\circ} \mathrm{E}$, alt. $1841 \mathrm{~m}, 25$ May-4 June 2014, Japoshvili G. leg., $\mathrm{H} 4$, deposited in IEAUG; $2 \widehat{\partial}^{\widehat{\partial}}$, Kakheti region, Lagodekhi, $41.885674^{\circ} \mathrm{N} 46.324132^{\circ} \mathrm{E}$, alt. 1902 m, 27 Sep.-6 Oct. 2014, Japoshvili G. leg., H4-5, deposited in MZBBU.

Biology: parasitoid of leaf-mining flies (Diptera, Agromyzidae), reared from Phytomyza species (Graham 1969).

Distribution: mainly distributed in Europe, but also reported from Kazakhstan, the Nearctic and the Russian Federation (Noyes 2019). New for the Caucasus and Georgia.

\section{Sphegigaster stepicola Bouček, 1965 *}

Material: GEORGIA - 1 ๙े, Kakheti region, Lagodekhi, $41.882783^{\circ} \mathrm{N} 46.321886^{\circ} \mathrm{E}$, alt.

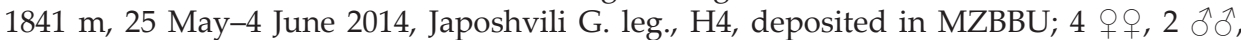
Kakheti region, Lagodekhi, $41.885674^{\circ} \mathrm{N} 46.324132^{\circ} \mathrm{E}$, alt. $1902 \mathrm{~m}, 4$ June-15 July 2014, Japoshvili G. leg., H4-5, half deposited in MZBBU and half in IEAUG.

Biology: parasitoid of leaf-mining flies (Diptera, Agromyzidae), reared from Phytomyza albiceps (Graham 1969), other Phytomyza, Agromyza, Ophiomyia and Melanagromyza species (Noyes 2019).

Distribution: distributed in the Palearctic, including Transcaucasia (BoučEK 1977) and South Asia including India and Thailand (Noyes 2019). New for Georgia.

\section{Genus Stictomischus Thomson, 1876 \\ Stictomischus obscurus (Walker, 1833) **}

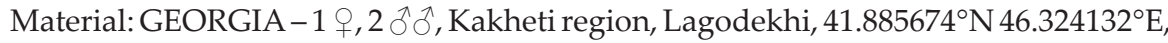
alt. 1902 m, 5-27 July 2014, Japoshvili G. leg., H4-5, deposited in MZBBU; 1 ㅇ, Kakheti region, Lagodekhi, $41.906257^{\circ} \mathrm{N} 46.333441^{\circ} \mathrm{E}$, alt. 2559 m, 15-25 June 2014, Japoshvili G. leg., H6, deposited in IEAUG.

Biology: parasitoid of leaf mining dipterans, with a record from Pegohylemyia seneciella on Jacobaea vulgaris (GraHAm 1969).

Distribution: widely distributed in Europe, but also reported from Kazakhstan, and the Russian Federation (Noyes 2019). Not recorded from the Caucasus or Georgia until now.

\section{Genus Trigonoderus Westwood, 1832 \\ Trigonoderus cyanescens (Förster, 1841) **}

(Fig. 3a)

Material: GEORGIA - 1 ㅇ, Kakheti region, Lagodekhi, $41.852441^{\circ} \mathrm{N} 46.287771^{\circ} \mathrm{E}$, alt. 666 m, 5-14 Sep. 2014, Japoshvili G. leg., H1, Malaise-trap, deposited in MZBBU; 1 , Kakheti region, Lagodekhi, $41.855848^{\circ} \mathrm{N} 46.292739^{\circ} \mathrm{E}$, alt. $847 \mathrm{~m}, 5-15$ July 2014, Japosh- 
vili G. leg., H2, Malaise-trap, deposited in MZBBU; 5 ㅇ, Kakheti region, Lagodekhi, $41.871523^{\circ} \mathrm{N} 46.311585^{\circ} \mathrm{E}$, alt. $1351 \mathrm{~m}, 5$ May-14 Sep. 2014, Japoshvili G. leg., H3, Malaisetrap, two specimens deposited in MZBBU, three specimens deposited in IEAUG.

Biology: parasitoid of Pogonocherus hispidus (Linnaeus, 1758) (Tudor 1971, LÁszló et al. 2013). Usually found in forest floor in oak-hornbeam forests.

Distribution: widely distributed in Europe. New for the Caucasus and Georgia.

\section{Trigonoderus pedicellaris Thomson, 1878 *}

(Fig. 3b)

Material: GEORGIA - 2 우, Kakheti region, Lagodekhi, $41.852441^{\circ} \mathrm{N} 46.287771^{\circ} \mathrm{E}$, alt. 666 m, 5 May-5 Aug. 2014, Japoshvili G. leg., H1, deposited in MZBBU; 3 우, Kakheti region, Lagodekhi, $41.855848^{\circ} \mathrm{N} 46.292739^{\circ} \mathrm{E}$, alt. $847 \mathrm{~m}, 25$ May-25 July 2014, Japoshvili G. leg., H2, deposited in MZBBU; 4 우, Kakheti region, Lagodekhi, $41.871523^{\circ} \mathrm{N} 46.311585^{\circ} \mathrm{E}$, alt. 1351 m, 15 June-14 Sep. 2014, Japoshvili G. leg., H3, deposited in IEAUG; 1 ㅇ, Kakheti region, Lagodekhi, $41.882783^{\circ} \mathrm{N} 46.321886^{\circ} \mathrm{E}$, alt. $1841 \mathrm{~m}$, 15-27 Sep. 2014, Japoshvili G. leg., H4, deposited in MZBBU; 1 ㅇ, Kakheti region, Lagodekhi, $41.885674^{\circ} \mathrm{N} 46.324132^{\circ} \mathrm{E}$, alt. 1902 m, 15-27 July 2014, Japoshvili G. leg., H4-5, deposited in MZBBU.

Biology: probably parasitoid of xylophagous beetles. Usually found in forest floor in oak-hornbeam forests.

Distribution: probably widely distributed in Europe: Austria, Croatia, Czech Republic, Italy, Hungary, Romania, Sweden, France and Spain (LÁszló et al. 2013). Not recorded from the Caucasus or Georgia until now.

\section{Trigonoderus princeps Westwood, 1832 *}

(Fig. 3c)

Material: GEORGIA - 1 , , Kakheti region, Lagodekhi, $41.852441^{\circ} \mathrm{N} 46.287771^{\circ} \mathrm{E}$, alt. 666 m, 8-15 Aug. 2014, Japoshvili G. leg., H1, deposited in IEAUG; 2 우어, Kakheti region, Lagodekhi, $41.855848^{\circ} \mathrm{N} 46.292739^{\circ} \mathrm{E}$, alt. 847 m, 4-25 June 2014, Japoshvili G. leg., H2, deposited in MZBBU.

Biology: parasitoid of xylophagous beetles: Scolytus ratzeburgi Janson, 1856 (Coleptera, Scolytidae) in birch (Betula sp.) and Parmena balteus (Linnaeus, 1767) (Coleoptera, Cerambycidae) in alder (Alnus glutinosa) (Kerrich \& Graham 1957, Graham 1969).

Distribution: widely distributed in Europe, but also reported from Japan, and the Russian Federation (Noyes 2019). Recorded from the Caucasus (BоučEK 1977), but not from Georgia until now.

\section{Trigonoderus pulcher Walker, $1836^{* *}$} (Fig. 3d)

Material: GEORGIA - 1 ㅇ, Kakheti region, Lagodekhi, $41.855848^{\circ} \mathrm{N} 46.292739^{\circ} \mathrm{E}$, alt. 847 m, 15-25 June 2014, Japoshvili G. leg., H2, deposited in MZBBU; 1 ㅇ, Kakheti region, Lagodekhi, $41.882783^{\circ} \mathrm{N} 46.321886^{\circ} \mathrm{E}$, alt. $1841 \mathrm{~m}$, 25 June-5 July 2014, Japoshvili G. leg., 
$\mathrm{H} 4$, deposited in MZBBU; 1 ㅇ, Kakheti region, Lagodekhi, $41.885674^{\circ} \mathrm{N} 46.324132^{\circ} \mathrm{E}$, alt. 1902 m, 25 July-5 Aug. 2014, Japoshvili G. leg., H4-5, deposited in IEAUG.

Biology: probably parasitoid of xylophagous beetles, one host plant record from Tilia sp. (Mitroiv et al. 2007).

Distribution: widely distributed in the Palearctic, with records from South Asia and the Russian Federation (Noyes 2019). New for the Caucasus and Georgia.

\section{Subfamily Pteromalinae Dalman, 1820}

\section{Genus Arthrolytus Thomson, 1878}

Arthrolytus maculipennis (Walker, 1835) *

Material: GEORGIA - 2 우우, Kakheti region, Lagodekhi, $41.855848^{\circ} \mathrm{N} 46.292739^{\circ} \mathrm{E}$, alt. 847 m, 25 Aug.-4 Sep. 2014, Japoshvili G. leg., H2, half deposited in MZBBU and half in IEAUG.

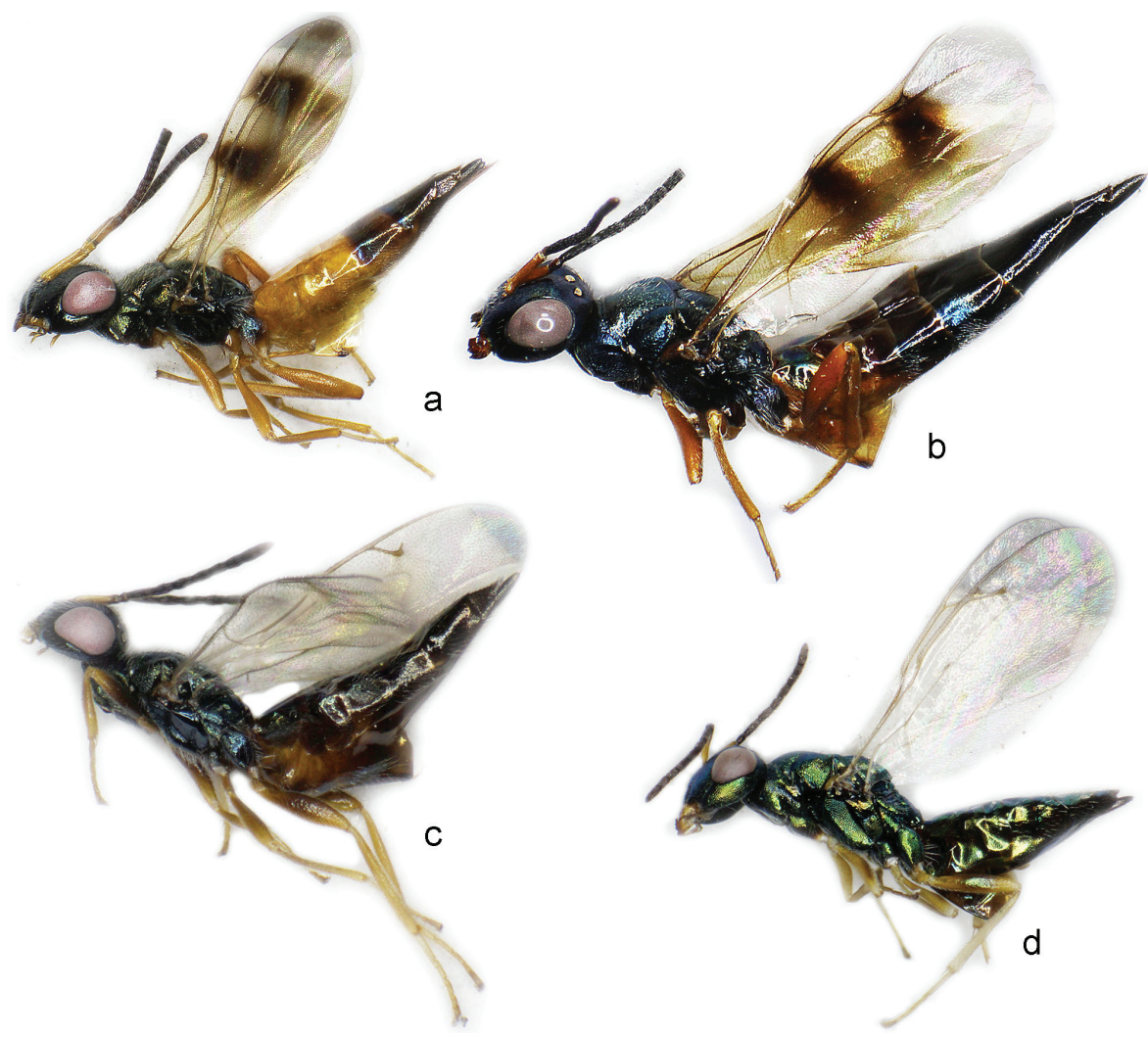

Fig. 3. Lateral view of species belonging to the genus Trigonoderus Westwood, 1832 collected in the Lagodekhi protected areas: $\mathrm{a}=$ Trigonoderus cyanescens (Förster, 1841), $\mathrm{b}=T$. pedicellaris Thomson, 1878, $\mathrm{c}=$ T. princeps Westwood, 1832, $\mathrm{d}=$ T. pulcher Walker, 1836 
Biology: parasitoid of Diptera, perhaps Cecidomyiidae, seems to be linked with gall inducers as congeneric species (GRAHAM 1969).

Distribution: widely distributed all over Europe and also mentioned from Sakhalin Oblast, which depicts a Palaearctic distribution (Noyes 2019). Was previously not mentioned from Georgia.

\title{
Genus Dinarmoides Masi, 1924 \\ Dinarmoides spilopterus Masi, $1924^{* *}$
}

Material: GEORGIA - 1 ㅇ, Kakheti region, Lagodekhi, $41.885674^{\circ} \mathrm{N} 46.324132^{\circ} \mathrm{E}$, alt. 1902 m, 15-25 July 2014, Japoshvili G. leg., H4-5, deposited in MZBBU.

Biology: unknown.

Distribution: it is known from Europe with adjacent islands and Middle East (Noyes 2019) from sandy or xerothermic habitats (Graнam 1969). New for the Caucasus and Georgia.

\author{
Genus Habritys Thomson, 1878 \\ Habritys brevicornis (Ratzeburg, 1844) **
}

Material: GEORGIA - 3 우, Kakheti region, Lagodekhi, $41.852441^{\circ} \mathrm{N} 46.287771^{\circ} \mathrm{E}$, alt. 666 m, 15 May-15 Aug. 2014, Japoshvili G. leg., H1, deposited in MZBBU; 1 +, Kakheti region, Lagodekhi, $41.855848^{\circ} \mathrm{N} 46.292739^{\circ} \mathrm{E}$, alt. $847 \mathrm{~m}, 15-25$ Aug. 2014, Japoshvili G. leg., $\mathrm{H} 2$, deposited in MZBBU; 2 우, Kakheti region, Lagodekhi, $41.871523^{\circ} \mathrm{N} 46.311585^{\circ} \mathrm{E}$, alt. 1351 m, 5 July-5 Aug. 2014, Japoshvili G. leg., H3, deposited in IEAUG; 1 , Kakheti region, Lagodekhi, $41.885674^{\circ} \mathrm{N} 46.324132^{\circ} \mathrm{E}$, alt. $1902 \mathrm{~m}, 5$ May-6 Oct. 2014, Japoshvili G. leg., H4-5, deposited in MZBBU.

Biology: it is mainly parasitoids of digger wasps (Hymenoptera: Sphecidae), but several bark beetles (Coleoptera: Scolytidae) has been also recorded as insect hosts, which are thought of being only secondary hosts while H. brevicornis parasitizes their hymenopteran parasitoids (Graham 1969).

Distribution: widely distributed in Europe, Middle East and the Nearctic, not recorded from the Caucasus or Georgia until now.

\section{Genus Psilocera Walker, 1833 \\ Psilocera crassispina (Thomson, 1878) **}

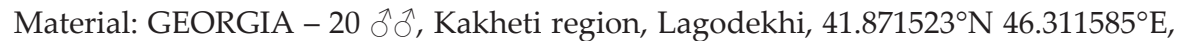
alt. 1351 m, 25 July-6 Oct. 2014, Japoshvili G. leg., H3, Malaise-trap, deposited in MZBBU; 3

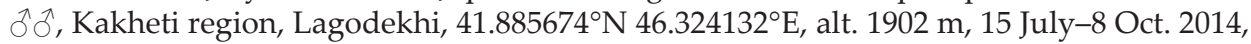
Japoshvili G. leg., H4-5, deposited in IEAUG; $1 \delta^{\lambda}$, Kakheti region, Lagodekhi, $41.906257^{\circ} \mathrm{N}$ 46.333441 ${ }^{\circ}$, alt. 2559 m, 15-25 Aug. 2014, Japoshvili G. leg., H6, deposited in IEAUG.

Biology: there is no information. In Graham's first key (1969) there is mentioned only at P. atra Walker, 1834 from this genus that it occurs "in grassy" situations. In GraHAm's (1992) later key no biological information is presented. In a faunistic paper of ANDRIESCU 
and Mitroiu (2004) the species is associated with Carduus pycnocephalus (Asteraceae) and Hordeum leparinum (Poaceae) (Noyes 2019).

Distribution: widely distributed in Europe (Graнam 1969), and also mentioned from Kazakhstan (Noyes 2019). Not recorded from the Caucasus or Georgia until now.

\section{Psilocera kartveli László et Kelemen sp. n.}

(Figs 4-5)

Diagnosis - The female Psilocera kartveli differs from P. obscura Walker, 1833 by the length of F1 related to the pedicellus, which in $P$. kartveli is clearly longer, while in P. obscura is at most barely as long as (Graham 1969). It also differs from P. obscura and P. concolor (Thomson, 1878) in the shape of the third flagellar segment, which is not anelliform, nor quadrate and hardly longer than broad, in P. kartveli F1 is clearly longer than broad. The female Psilocera kartveli differs from P. crassispina (Thomson, 1878) by the setation of the basal cell: in P. crassispina basal cell of fore wing having its distal half or more pilose, while in P. kartveli the basal cell has only a few hairs distally. Psilocera kartveli females differ from P. rufipes Graham, 1992, P. confusa Graham, 1992 and P. crassispina in the ratio of POL to OOL, which is about 0.9 , while in the case of the other three species is about 0.65 . Considering the species described from Asia in Sureshan (2014) the closest species to P. kartveli are P. ghanii Subba Rao, 1981, P. vinayaki Sureshan et Narendran, 1995 and P. namdaphaensis Sureshan, 2014. The antennal clava of $P$. ghanii is shorter than three preceding segments combined, while in $P$. kartveli the clava is as long as three preceding segments. The scutellum of $P$. vinayaki has long white bristles, while $P$. kartveli has dark bristles. The clava of $P$. namdaphaensis is as long as preceding $3.5 \mathrm{seg}-$ ments combined and its scape does not reach median ocellus, while P. kartveli has a clava equal to three preceding segments its scape reaches over the lower edge of median ocellus.

The males of $P$. kartveli differ from $P$. pandens in the ratio of $F 1$ length to pedicel length: while in P. pandens the ratio is about 3.5 (Graham 1974, Graham 1992), in the case of $P$. kartveli the ratio of $\mathrm{F} 1$ is 2.4 . The males of $P$. kartveli differ from P. punctifrons (Thomson, 1878) by the shape of F6, which in P. punctifrons is only slightly transverse (Graham 1992), but in P. kartveli is strongly transverse.

Etymology - The species name "kartveli" is an adjective formed from the Georgian name of Georgian person: "kartveli".

Material examined - Holotype: GEORGIA, 1 , Kakheti region, Lagodekhi, $41.855848^{\circ} \mathrm{N} 46.292739^{\circ} \mathrm{E}$, alt. 847 m, 25 Aug.-4 Sep. 2014, Japoshvili G. leg., H2, Malaisetrap, deposited in MZBBU, specimen code: HYM000026. Paratypes: GEORGIA - 1 , Kakheti region, Lagodekhi, $41.855848^{\circ} \mathrm{N} 46.292739^{\circ} \mathrm{E}$, alt. 847 m, 5-14 Sep. 2014, Japoshvili 
G. leg., H2, Malaise-trap, deposited in IEAUG, specimen code: HYM000027; 1 q, Kakheti region, Lagodekhi, $41.871523^{\circ} \mathrm{N} 46.311585^{\circ} \mathrm{E}$, alt. $1351 \mathrm{~m}, 15-25$ June 2014, Japoshvili G. leg., H3, Malaise-trap, deposited in MZBBU, specimen code: HYM000028; 1 ô, Kakheti region, Lagodekhi, $41.855848^{\circ} \mathrm{N} 46.292739^{\circ} \mathrm{E}$, alt. $847 \mathrm{~m}, 25 \mathrm{May}-4$ June 2014, Japoshvili

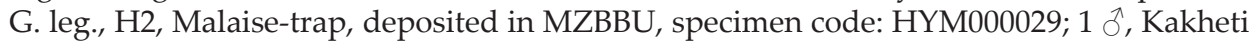
region, Lagodekhi, $41.855848^{\circ} \mathrm{N} 46.292739^{\circ} \mathrm{E}$, alt. $847 \mathrm{~m}$, 25 June-5 July 2014, Japoshvili G. leg., H2, Malaise-trap, deposited in IEAUG, specimen code: HYM000030; 1 ô, Kakheti region, Lagodekhi, $41.852441^{\circ} \mathrm{N} 46.287771^{\circ} \mathrm{E}$, alt. 666 m, 23 Apr.-15 Aug. 2014, Japoshvili G. leg., H1, Malaise-trap, deposited in MZBBU, specimen code: HYM000031; 1 ô, Kakheti region, Lagodekhi, $41.871523^{\circ} \mathrm{N} 46.311585^{\circ} \mathrm{E}$, alt. $1351 \mathrm{~m}$, 5-15 July 2014, Japoshvili G. leg., H3, Malaise-trap, deposited in MZBBU, specimen code: HYM000032; 1 \%, Kakheti region, Lagodekhi, $41.885674^{\circ} \mathrm{N} 46.324132^{\circ} \mathrm{E}$, alt. $1902 \mathrm{~m}$, 15-27 July 2014, Japoshvili G. leg., H4-5, Malaise-trap, deposited in IEAUG, specimen code: HYM000033.

Description of females - holotype [2 paratypes] (Fig. 4). Body length: 3.5 [min. $=3.45$ max. $=3.55] \mathrm{mm}$

Colour - Head blackish, with dark coppery green tinge. Scape, pedicel and anelli yellow. Proximal majority of F1 pale, reddish, remaining antennal segments and clava black, with micropilosity area pale, reddish. Ocelli concolorous with compound eyes, silvery. Mandibles reddish, with dark tips. Mesosoma blackish, with dark coppery green tinge. Pronotum mostly blackish, central lobe of mesoscutum and scutellum coppery green. Mesopleuron and propodeum blackish, with a violet-bluish tinge. Coxae mostly blackish, with a faint bluish tinge. Femora, tibiae and tarsi yellowish-red. Wings hyaline, fore wing with a shallow fuscous cloud from the basal cell trough the wing disc. Metasoma dark, brownish coppery green. Setae light coloured, darker on the head and dorsal part of mesosoma, whitish on lateral parts of meso- and metasoma.

Head - Reticulation moderate and uniform. In dorsal view 2.29 times as broad as long (head breadth: 80 [78-80], head length: 35 [35-37] on 60×) and 1.8 times as broad as mesoscutum (mesoscutum breadth: 63 [62-63] on 60×). POL 1.07 times OOL (POL: 15 [15-15], OOL: 14 [14-15] on 60×). Eye length 2.2 times as long as temple (temple: 10 [10-11], eye length: 22 [21-22] on 60×). Vertex from a lateral view sharply pointed. Head height between lower margin of clypeus and lower margin of anterior ocellus in frontal view 0.74 times head breadth (head height: 59 [58-60] on 60×). Eyes separated by 1.41 times their height at the level of toruli (eye distance: 55 [55-56], eye height: 39 [39-41] on 60×). Malar space 0.64 times eye height in frontal view (malar space: 25 [24-25] on 60×). Anterior margin of clypeus with two distinct teeth, radiately striated, striae reaching up to ventral edge of eye. Face moderately reticulate, except for a broad shining area above clypeus, pubescence whitish, sparse, denser on lower part of face. Scrobe deep, reaching median ocellus. Antenna inserted below middle of face: lower face (distance between lower margin of clypeus and lower margin of antennal toruli: 27 [27] on 60×) 0.66 times upper face (distance between lower margin of antennal toruli and lower margin of anterior ocellus: 35 [33-35] on 60× magnification) in frontal view. Scape shorter than upper face, not reaching median ocellus. Scape length (29 [29-30] on 60×) 0.74 times eye height. Pedicel (10 [10] on $80 \times$ ) shorter than F1 (13 [12-14] on 80×). Pedicel plus flagellum (67 [67-70] on 80×) 0.81 times head breadth. Flagellum strongly clavate, breadth of clava (13 [13] on 80×) 1.88 times breadth of F1 (7 [7-8] on 80×). Both anelli transverse, second a little longer than the first. F1 (13 [12-14] on 80×) longer than F2 (11 [10-11] on 80×). All funicular segments with one row of long sensilla. F1-F3 longer than broad. F4 quadrate, a little shorter than F3, F5-F6 trans- 


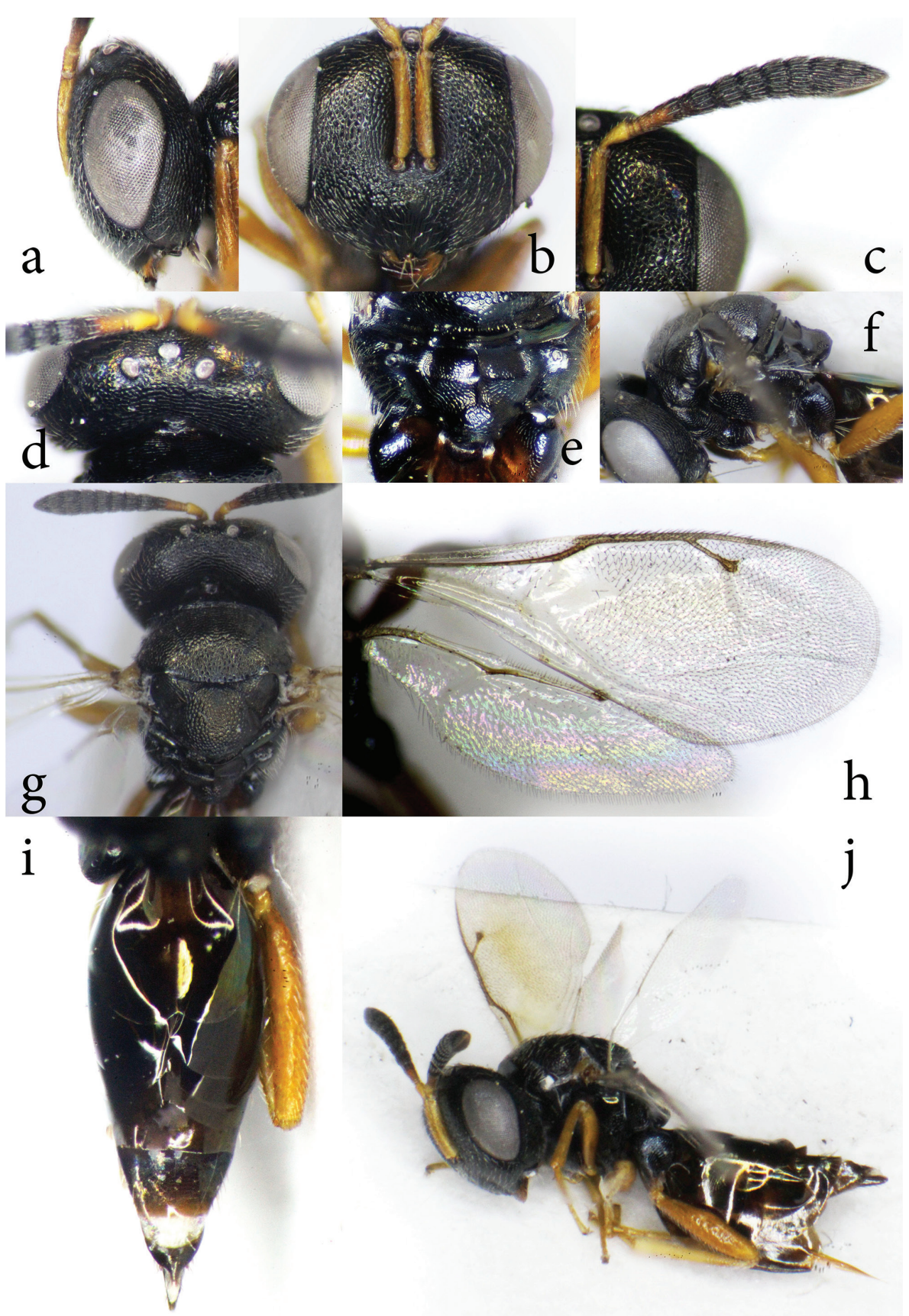

Fig. 4. Psilocera kartveli sp. $n$. holotype female: $\mathrm{a}=$ head in lateral view, $\mathrm{b}=$ head in frontal view, $\mathrm{c}=$ antenna, $\mathrm{d}=$ head in dorsal view, $\mathrm{e}=$ propodeum, $\mathrm{f}=$ mesosoma in lateral view, $\mathrm{g}=$ mesosoma in dorsal view, $\mathrm{h}=$ right side wings, $\mathrm{i}=$ gaster in dorsal view, $\mathrm{j}=$ habitus in lateral view 
verse, a little shorter than F4. Clava 1.92 times as long (25 [25-27] on 80×) as broad (13 [13] on $80 \times$ ). Clava as long as the three preceding segments combined, sutures oblique, clearly distinct, micropilosity area (17 [17] on 80×) 0.68 times length of clava.

Mesosoma - Sparsely pubescent and with sparse whitish bristles. Pronotal collar reticulate, anteriorly carinate in the middle. Mesoscutum and scutellum reticulate. Mesoscutum 2.1 times as broad (63 [62-63] on 60×) as long (30 [30-32] on 60×) with notauli incomplete. Scutellum (30 [29-30] on 60×) as long as mesoscutum, without any conical projection, frenum clearly marked. Axilla and axillula finely reticulate. Dorsellum narrow, very finely reticulate. Propodeum medially 0.73 times as long (22 [21-23] on 60×) as scutellum, in dorsal view 2.59 times as broad (57 [57-58] on 60×) as long, propodeum finely reticulate, median carina and costula distinct and complete, plicae indicated only in anterior half, spiracles oval, not touching hind margin of metanotum, post-spiracular sulcus deep, callus with long thick white pubescence. Prepectus small, narrow, fine, as long as tegula. Mesopleuron moderately reticulate with a broad triangular shiny area below hind wing. Metapleuron moderately reticulate. Fore wing 2.5 times as long (75 [73-75] on 30×) as broad (30 [30-31] on 30×), marginal fringe very small, almost indistinct, pubescence moderate, basal cell open below with 6 or 7 scattered setae distally, costal cell only distally hairy on the dorsal surface, speculum open below. Relative lengths of submarginal vein: 54 [54-55], marginal vein: 28 [28-31], stigma vein: 13 [13-15], postmarginal vein: 26 [25-26] (on 60×). Legs slender, hind coxa densely hairy on antero-lateral margins, 1.26 times as long (24 [24-25] on 60×) as broad (19 [17-19] on 60×), hind femora 4 times as long (52 [52-54] on 60×) as broad (13 [12-13] on 60×), hind tibiae 1.15 times as long (60 [58-60] on $60 \times)$ as femora, hind tibia with one spur.

Metasoma - Petiole short, distinct. Gaster lanceolate (70 [69-71] on 40×, including ovipositor sheaths), 1.21 times longer than mesosoma (57 [57-59] on 40×), dorsally collapsing, and, in dorsal view 2.5 times as long as broad (28 [23-28] on 40×). Hind margins of T1-T4 deeply incised medially.

Description of males (4 paratypes) (Fig. 5) - Body length 2.25 [min. $=1.8-$ max. $=2.45]$ $\mathrm{mm}$.

Colour - Head and mesosoma bluish black. Scape, pedicel and first anellus yellow. Antennal segments and clava black, with whitish hairs. Ocelli concolorous with compound eyes, silvery. Mandibles yellow, with reddish dark tips. Coxae concolorous with the mesosoma. Femora dark brown, tibiae yellowish brown and tarsi yellow. Wings hyaline. Metasoma dark, proximal tergites brownish, distal tergites black. Setae light coloured.

Head - Reticulation moderate and uniform. In dorsal view 2.43 times as broad as long (head breadth: 51 [47-60], head length: 21 [19-25] on 60×) and 1.24 times as broad as mesoscutum (mesoscutum breadth: 41 [39-50] on 60×). POL 1.1 times OOL (POL: 11 [11-13], OOL: 10 [10-13] on 60×). Eye length 2.4 times as long as temple (temple: 5 [5-9], eye length: 12 [12-14] on 60×). Head height between lower margin of clypeus and lower margin of anterior ocellus in frontal view 0.71 times head breadth (head height: 36 [35-45] on 60×). Eyes separated by 1.75 times their height at the level of toruli (eye distance: 35 [35-44], eye height: 20 [19-25] on 60×). Malar space 0.75 times eye height in frontal view (malar space: 15 [15-20] on 60×). Anterior margin of clypeus with two distinct teeth, radiately striated, striae reaching up to base of eye. Face moderately reticulate, except for a broad shining area above clypeus, pubescence whitish, sparse. Scrobe deep, reaching median ocellus. Antenna inserted below middle of face: lower face (distance between lower margin of clypeus and lower margin of antennal toruli: 19 [18-25] on 60×) is 1.05 times upper face (distance between lower margin of antennal toruli and lower margin of anterior ocellus: 18 [17-20] on $60 \times$ magnification) in frontal view. Scape longer than upper face, reaching to the upper 


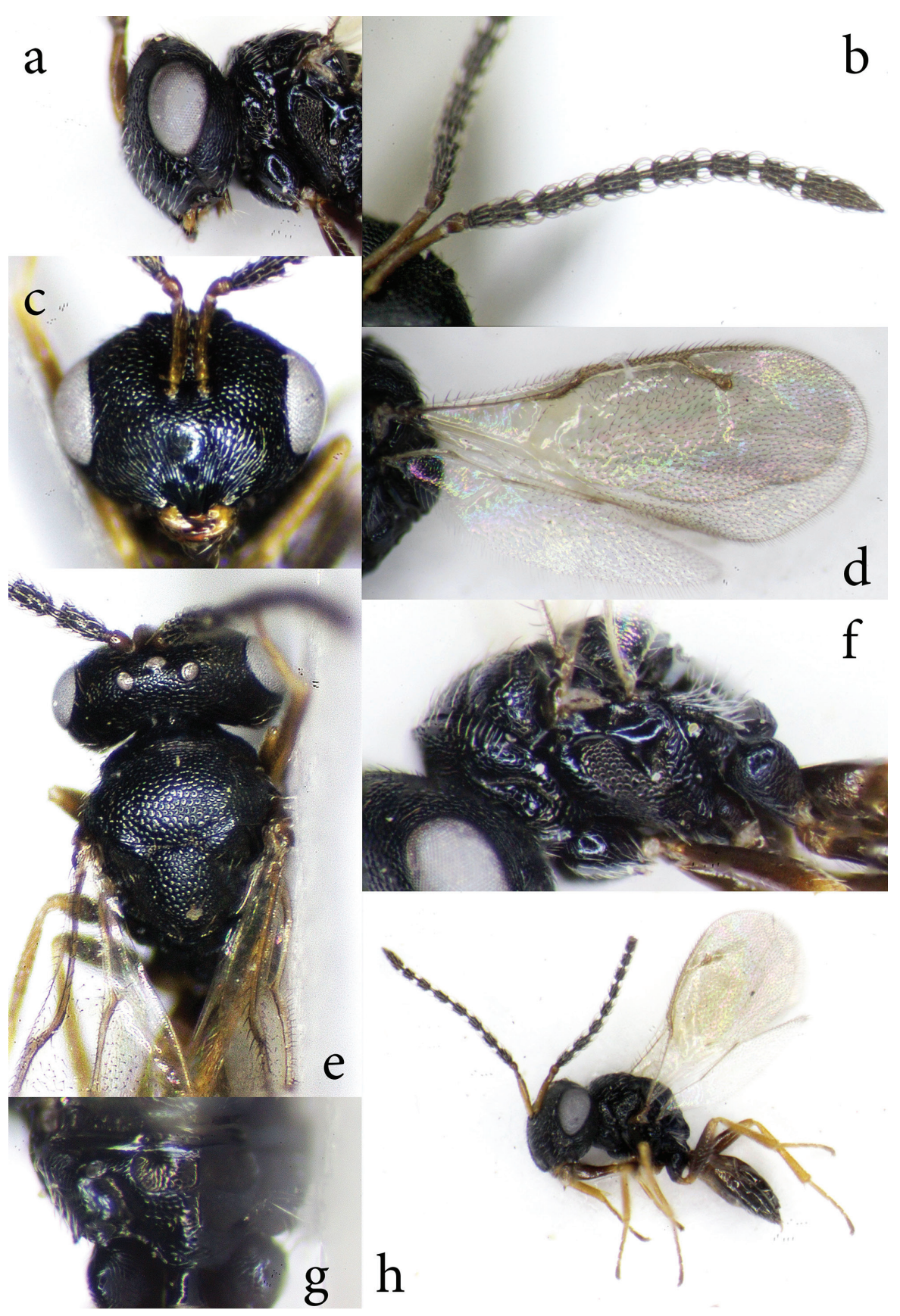

Fig. 5. Psilocera kartveli sp. $\mathrm{n}$. paratype male: $\mathrm{a}=$ head in lateral view, $\mathrm{b}=$ antenna, $\mathrm{c}=$, head in frontal view $\mathrm{d}=$ right side wings, $\mathrm{e}=$ mesosoma in dorsal view, $\mathrm{f}=$ mesosoma in lateral view, $\mathrm{g}=$, propodeum $\mathrm{h}=$ habitus in lateral view 
margin of the median ocellus. Scape length (18 [18-23] on 60×) 0.9 times eye height. Antenna with funicle with only six segments separated by peduncles, clava three-segmented, hairs of flagellum standing out less strongly. Pedicel (5 [5-8] on 80×) shorter than F1 (12 [12-17] on 80×). Pedicel plus flagellum (91 [87-108] on 80×) 1.78 times head breadth. F1-F6 all longer than broad. Breadth of all funicular segments and clava 5 [5-8] (on 80×). Both anelli transverse. F1 as long as F2. F3 and F4 longer (11 [9-14] on 80×) than F5 and F6 (10 [811] on $80 \times$ ) without peduncles. All funicular segments with three rows of long hairs. Clava as long $(20$ [18-25] on $80 \times)$ as the two preceding segments combined without peduncles.

Mesosoma - Sparsely pubescent and with sparse whitish bristles. Prontoal collar, mesoscutum and scutellum moderately reticulate. Mesoscutum 2.05 times as broad (41 [39-50] on $60 \times)$ as long (19 [19-23] on 60×) with notauli incomplete. Scutellum (20 [20-26] on $60 \times$ ) as long as mesoscutum, without any conical projection. Axilla and axillula finely reticulate. Dorsellum narrow. Propodeum medially 0.7 times as long (14 [14-17] on 60×) as scutellum, in dorsal view 2.71 times as broad (38 [36-45] on 60×) as long. Propodeum finely reticulate, median carina and costula distinct and complete, plicae indicated only in anterior half. Spiracles oval, not touching hind margin of metanotum, post-spiracular sulcus deep, callus with long thick white pubescence. Prepectus small, narrow, fine, as long as tegula. Mesopleuron reticulate with a broad triangular shiny area below hind wing. Metapleuron moderately reticulate. Forewing 2.03 times as long (55 [51-67] on 30×) as broad (27 [25-32] on 30×). Basal cell open below with 4 or 5 scattered hairs distally, basal hairline indicated by 6 hairs, costal cell only distally hairy on the dorsal surface, speculum open below. Relative lengths of submarginal vein: 42 [39-50], marginal vein: 23 [19-30], stigma vein: 15 [13-29], postmarginal vein: 16 [16-23] (on 60×). Legs slender, hind coxa densely hairy on antero-lateral margins, 1.6 times as long (16 [15-22] on 60×) as broad (10 [10-12] on 60×), hind femora 4.85 times as long (34 [31-42] on 60×) as broad (7 [6-8] on 60×), hind tibia as long (34 [31-45] on $60 \times$ ) as femora, hind tibia with one spur.

Metasoma - Petiole distinct, longer than broad. Gaster (55 [33-55] on 40×, including ovipositor sheaths) as long as mesosoma (37 [34-46] on 40×), dorsally collapsing, and, in dorsal view 2.5 times as long as broad (22 [18-22] on 40×).

\title{
Subfamily Spalangiinae Haliday, 1833
}

\author{
Genus Spalangia Latreille, 1805 \\ Spalangia nigripes Curtis, 1839 **
}

Material: GEORGIA - 1 ㅇ, Kakheti region, Lagodekhi, $41.855848^{\circ} \mathrm{N} 46.292739^{\circ} \mathrm{E}$, alt. 847 m, 12-23 Apr. 2014, Japoshvili G. leg., H2, deposited in MZBBU.

Biology: parasitoid of Diptera belonging to Muscidae and Calliphoridae (GiBson 2009).

Distribution: it is widely distributed in the Palearctic (Noyes 2019), but confirmed also from the Nearctic (Gibson 2009). New for the Caucasus and Georgia.

\section{DISCUSSION}

The identified species increase the number of recorded pteromalids from Georgia from 18 to 39. Also, the number of recorded subfamilies of the same family from Georgia increased from 4 to 9 . However, these taxa numbers are 
still very small compared to the potential species richness of the family and the habitat diversity in the Caucasus. Considering the remaining material collected by Malaise-traps in the Lagodekhi protected areas to be identified, the pteromalid species number from the Caucasus and Georgia will certainly increase at second hand above one hundred species.

Acknowledgements - The work of Japoshvili G. was supported by the Rustaveli National Science Foundation under grant FR/221/7-110/13. We thank two anonymous reviewers for improving the manuscript.

\section{REFERENCES}

Andriescu, I. \& Mitroiu, M.-D. (2004): Notes on the pteromalid fauna (Hymenoptera: Chalcidoidea, Pteromalidae) of Dobrogea, Romania (II). - Analele Ştiințifice ale Universităţii "Al. I. Cuza" Iaşi, s. Biologie animală 50: 89-96.

BoučEK, Z. (1977): A faunistic review of the Yugoslavian Chalcidoidea (parasitic Hymenoptera). - Acta Entomologica Jugoslavica 13(Suppl.): 1-145.

BoučEK, Z. (1961): A new species of Notanisus Walk from Georgia, USSR (Hym. Pteromalidae). - Sborník Entomologického Oddeleni Národního Musea v Praze 34: 471-474.

BoučEK, Z. (1966): Contribution to the chalcid fauna of the Moldavian SSR (Hymenoptera, Chalcidoidea). - Proceedings of the Moldovan Scientific Research Institute of Horticulture, Viticulture and Winemaking 13: 15-38.

BoučEK, Z. (1972): On European Pteromalidae (Hymenoptera): a revision of Cleonymus, Eunotus, Spaniopus, with description of new genera and species. - Bulletin of the British Museum (Natural History) (Entomology) 27(5): 267-315.

BoučEK, Z. (1958): To the taxonomy of the European species of Schizonotus and Caenocrepis - parasites of economic importance - with notes, and some synonymy in Pteromalidae and Eurytomidae (Hym.). - Sborník Entomologického Oddeleni Národního Musea v Praze 32: 395-404.

Boucek, Z. \& Heydon, S. L. (1997): Chapter 17. Pteromalidae. Pp. 541-692. In: Gibson, G. A. P., Huber, J. T. \& Wooley, J. B. (eds): Annotated keys to the genera of Nearctic Chalcidoidea (Hymenoptera). - NRC CNRC, Ottawa, Ontario.

BoučEK, Z. \& RAsplus, J.-Y. (1991): Illustrated key to West-Palearctic genera of Pteromalidae (Hymenoptera: Chalcidoidea). - Institut National de la Recherche Agronomique (INRA), $140 \mathrm{pp}$.

Desjardins, C. A., Regier, J. C. \& Mitter, C. (2007): Phylogeny of pteromalid parasitic wasps (Hymenoptera: Pteromalidae): Initial evidence from four protein-coding nuclear genes. - Molecular Phylogenetics and Evolution 45(2): 454-469.

https://doi.org/10.1016/j.ympev.2007.08.004

Dzhanokmen, K. A. (1988): 5. Family Pteromalidae (Pteromalids). Pp. 88-411. In: MedveDEv, G. S. (ed.): Keys to the insects of the European part of the USSR. - E. J. Brill, Leiden, The Netherlands.

Dzhanoкmen, K. A. (1978): Hymenoptera III. Chalcidoidea 5. Pteromalidae. - Opredeliteli Nasekomykh Evropeyskoy Chasti SSR 3: 57-228. 
Dzhanokmen, K. A. (1982): New species of pteromalids (Hymenoptera, Chalcidoidea, Pteromalidae) from Kazakhstan and Georgia. - Trudy Zoologicheskogo Instituta, Akademiya Nauk SSSR 110: 94-98.

Dzhanokmen, K. A. (2005): Synoptic list of the Pteromalidae (Hymenoptera, Chalcidoidea) from Kazakhstan and middle Asia. - TETHYS Entomological Research 11: 61.

Gibson, G. A. P. (2009): Revision of New World Spalangiinae (Hymenoptera: Pteromalidae). - Zootaxa 2259: 1-159. https://doi.org/10.11646/zootaxa.2259.1.1

Graham, M. W. R. de V. (1992): Second revision of Western European Psilocera (Hym., Pteromalidae) with descriptions of three new species. - Entomologist's Monthly Magazine 128: 15-21.

Graham, M. W. R. de V. (1969): The Pteromalidae of North-Western Europe. - Bulletin of the British Museum (Natural History) Entomology Suppl. 16: 1-909. https://doi.org/10.5962/p.258046

Graham, M. W. R. de V. (1974): The type-specimen of Pteromalus pandens Walker (Hymenoptera: Chalcidoidea) in Budapest. - Folia entomologica hungarica 27(2): 71-73.

Heraty, J. M., Burks, R. A., Cruaud, A., Gibson, G. A. P., Liljeblad, J., Munro, J., Rasplus, J. Y., Delvare, G., Janšta, P., Gumovsky, A., Huber, J., Woolley, J. B., Krogmann, L., Heydon, S., Polaszek, A., Schmidt, S., Darling, D. C., Gates, M. W., Mottern, J., Murray, E., Dal Molin, A., Triapitsyn, S., Baur, H., Pinto, J. D., van Noort, S., George, J. \& Yoder, M. (2013): A phylogenetic analysis of the megadiverse Chalcidoidea (Hymenoptera). - Cladistics 29(5): 466-542. https://doi.org/10.1111/cla.12006

Japoshvili, G. \& Karaca, I. (2002): Coccid (Homoptera: Coccoidea) species of Isparta Province, and their parasitoids from Turkey and Georgia. - Turkish Journal of Zoology 26(4): 371-376.

Japoshvili, G. O. (2002): Chalcids from South Georgia. Pp. 291-293. In: Melika, G. \& Thuróczy, C. (eds): Parasitic wasps: Evolution, systematics, biodiversity and biological control. - Agroinform, Budapest.

Kerrich, G. J. \& Graham, M. W. R. de V. (1957): Systematic notes on British and Swedish Cleonymidae, with description of a new genus (Hym. Chalcidoidea). - Transactions of the Society for British Entomology 12(7): 265-311.

LÁszló, Z., BAuR, H. \& TóthméRÉsz, B. (2013): Multivariate ratio analysis reveals Trigonoderus pedicellaris Thomson (Hymenoptera, Chalcidoidea, Pteromalidae) as a valid species. - Systematic Entomology 38(4): 753-762. https://doi.org/10.1111/syen.12026

Mitroiu, M., Andriescu, I., Fusu, L. \& Dascalu, M.-M. (2007): Pteromalids (Hymenoptera: Pteromalidae) new to Romania, obtained from rearings. - Analele Stiintifice ale Universitatii "Al. I. Cuza" Iasi, s. Biologie animala 53: 135-140.

Munro, J. B., Heraty, J. M., Burks, R. A., Hawks, D., Mottern, J., Cruaud, A., Rasplus, J. Y. \& JANSTA, P. (2011): A molecular phylogeny of the chalcidoidea (Hymenoptera). PLoS ONE 6(11). https://doi.org/10.1371/journal.pone.0027023

Noyes, J. (2019): Universal Chalcidoidea Database. World Wide Web electronic publication. http://www.nhm.ac.uk/chalcidoids

Рroкореnкo, A. I. \& Moкrousova, L. A. (1981): Scutellista as a biological controller of the Japanese wax scale. - Zashchita Rasteniy 16(12): 43-44.

Sureshan, P. M. (2014): Description of three new species of Psilocera Walker from India, with a key to the Oriental species (Hymenoptera: Chalcidoidea: Pteromalidae). Journal of Threatened Taxa 6(6): 5851-5857. https://doi.org/10.11609/jott.o3654.5851-7

Töвӧк, M. \& Авванам, R. (2002): Sampling ground or truly monophyletic? Clasidistic analyses applied to the phylogeny of (Hymenoptera: Chalcidoidea). Pp. 54-72. In: 
Melika, G. \& Thuróczy, C. (eds): Parasitic wasps: Evolution, systematics, biodiversity and biological control. - Agroinform, Budapest.

Tselikh, E. V. (2011): A new genus of the family Pteromalidae (Hymenoptera, Chalcidoidea) from the Russian Far East. - Far Eastern Entomologist 237: 1-12. https://doi.org/10.1134/S001387381707014X

Tudor, C. (1971): Data noi asupra Chalcidoidelor (Hymenoptera - Chalcidoidea) din Romania. - Analele Universitatii Bucuresti (Biologie Animale) 20: 101-104.

Van Driesche, R., Hoddle, M. \& Center, T. (2008): Control of pests and weeds by natural enemies: an introduction to biological control. Vol. 46. - Blackwell Publishing, 502 pp.

Werner, J. \& Peters, R. S. (2018): Taxonomic revision of the genus Oodera Westwood, 1874 (Hymenoptera, Chalcidoidea, Pteromalidae, Cleonyminae), with description of ten new species. - Journal of Hymenoptera Research 63: 73-123.

https://doi.org/10.3897/jhr.63.12754

Yasnosh, V. A. (1972): Khalitsidy (Hymenoptera, Chalcidoidea) - parazity koktsid (Homoptera, Coccidae) aridnykh redtolesiy Grusii. - Trudy Vsesoyuznogo Entomologicheskogo Obshchestva 55: 217-247.

Yasnosh, V. A., Rtskhiladze, M. \& Tabatadze, E. (2001): Coccids (Hemiptera, Coccinea) and their natural enemies in the vineyards of Georgia: present situation. - Bollettino di Zoologia Agraria e Bachicoltura 33(3): 351-355.

Received March 17, 2021, accepted November 6, 2021, published February 14, 2022 